\title{
PENGARUH SERTIFIKASI TERHADAP MOTIVASI KERJA, KEPUASAN KERJA \& KINERJA GURU BK SMAN
}

\author{
Kulasse Kanto \\ Ahli Bimbingan Konseling \\ Fakultas Ilmu Pendidikan, Universitas Negeri Makassar \\ Email: kulassekanto@yahoo.com
}

\begin{abstract}
This study examines the influence of certification on Guidance and Counseling teacher performance in in state high schools in South Sulawesi. The objective analysis of this study was to determine (i) Potrait or description of certification, either by portfolio certification or training on guidance and counseling teacher performance at school (ii) To know any effect of certification either by portfolio certification and training on guidence and counseling teacher performance, work motivation and job satisfaction at school (iii) To know any effect not certified on guidence and counseling teacher performance, work motivation and job satisfaction at school. The method used is quantitative survey and instrument used is assessment scale and documentation. Data processing techniques with path analysis models of Amos to test the influence (certification, motivation, satisfaction and performance) and ANOVA of differences test (portfolio, training and pre-certification) with descriptive preceded.. Population and sample of the study was teachers of guidance and conseling in state high school in South Sulawesi with 373 people of population and the samples were taken with a stratified random sampling technique (sampling area), amounting to 163 people on the subject for eight city/region in the eastern, southern, central and northern area. The results of the study are (i) an overview description of the certification of the performance, motivation and job satisfaction of guidance and counseling teachers tend to vary, but do not have significant differences. While the normal curve graph shows not occur in the extreme declivity. (ii) there is effect of certification on work motivation and job satisfaction, (iii) there is effect of work motivation and job satisfaction on the performance of counselors on specific performance assessment, and (iv) there is effect of job satisfaction on work motivation of counselor in school.
\end{abstract}

Keywords: Certification (Portfolio and Training), Work Motivation, Job Satisfaction and Performance Counselor.

\begin{abstract}
ABSTRAK
Penelitian ini mengkaji masalah utama yaitu pengaruh sertifikasi terhadap kinerja guru Bimbingan dan Konseling yang bertugas di SMA Negeri di Sulawesi Selatan. Tujuan penelitian untuk mengetahui (i) potret atau gambaran deskripsi sertifikasi bentuk portofolio dan pelatihan terhadap motivasi kerja, kepuasan kerja dan kinerja guru bimbingan dan konseling, (ii) pengaruh sertifikasi terhadap motivasi kerja, kepuasan kerja dan kinerja konselor, (iii) pengaruh motivai kerja dan kepuasan kerja terhadap kinerja konselor dan (iv) pengaruh kepuaan kerja terhadap motivasi kerja konselor. Metode yang digunakan adalah survey yang bersifat kuantitatif dan instrumen yang digunakan adalah skala penilaian dan dokumentasi. Teknik pengolahan data dengan Analisis Jalur model Amos untuk uji pengaruh (sertifikasi, motivasi, kepuasan dan kinerja) dan Anava uji perbedaan dengan didahului Analisis Deskriptif. Populasi dan sampel penelitian ini adalah konselor SMAN di Sulawesi Selatan populasi berjumlah 304 orang dan sampel yang diambil dengan teknik stratified random sampling (area sampling) yang berjumlah 163 orang pada subjek untuk delapan Kota/Kabupaten pada
\end{abstract}




\begin{abstract}
area timur, selatan, tengah dan utara. Hasil penelitian adalah (i) gambaran deskripsi mean atau rata-rata, median dan standard deviation pada kinerja, motivasi dan kepuasan kerja guru bimbingan dan konseling cenderung bervariasi, tetapi tidak memiliki perbedaan signifikan, dan menunjukkan kurve-normal, tidak mencong ke kiri atau mencong ke kanan secara ekstrim. (ii) ada pengaruh sertifikasi terhadap motivasi kerja dan kepuasan kerja, (iii) ada pengaruh motivasi kerja dan kepuasan kerja terhadap kinerja konselor pada penilaian kinerja tertentu, dan (iv) ada pengaruh kepuasan kerja terhadap motivasi kerja konselor di sekolah.
\end{abstract}

Kata Kunci: Sertifikasi, Motivasi kerja, Kepuasan kerja, dan Kinerja.

\section{PENDAHULUAN}

Penting diperhatikan oleh semua pihak terutama pemerintah, khususnya bidang Kementerian Pendidikan dan Kebudayaan dari atas kebawah, mulai menteri sampai pada pengawas dan kepala sekolah. Pihak-pihak tersebut dapat senantiasa memberi pembinaan, pemantauan, koordinasi, dan pengawasan yang lebih kondusif, terarah dan lebih bersifat produktif bagi konselor di sekolah. Penilaian kepala sekolah dan pengawas sekolah perlu dilakukan secara terprogram dan kontinyu. Berbagai upaya harus dilakukan untuk mencapai hasil pendidikan yang berkualitas, salah satunya adalah peningkatan kinerja konselor sekolah. Peningkatan kinerja konselor secara profesional perlu diperhatikan untuk memotivasi agar bekerja dengan penuh semangat dengan kepuasan memadai, dengan kata lain mendorong konselor untuk bekerja keras dan memberdayakan tingkat kepuasan yang optimal bagi konselor yang memiliki kinerja profesional.

Kebijakan pemerintah untuk meningkatkan mutu pendidikan, khususnya mutu pelayanan bimbingan dan konseling dengan sertifikasi pendidik. Terdapat UU dan PP yang mendasari pelakanaan sertifikasi pendidik. Utamanya adalah adanya penggunaan istilah konselor sebagai pendidik profesional (istilah pada pasal 1 ayat 6 UUSPN No 20 th 2003). Kemudian disusul UU tentang Guru dan Dosen No 14 th 2005. Akhirnya PP RI No 19 th 2005 tentang SNP menyatakan bahwa guru dan konselor adalah pendidik profesional yang menguasai berbagai kompetensi sebagai agen pembelajaran.

Tujuan dan manfaat sertifikasi konselor adalah: (a) menentukan kelayakan dalam mewujudkan tujuan pendidikan nasional, (b) meningkatkan proses dan mutu hasil pendidikan, (c) meningkatkan martabat keguruan, dan (d) meningkatkan profesionalitas guru dan konselor sebagai agen pembelajaran di samping sebagai perwujudan pencapaian tujuan pendidikan nasional. Adapun manfaat sertifikasi konselor lebih lanjut diperinci sebagai berikut: (a) melindungi profesi konselor dari praktik-praktik yang tidak kompeten, (b) melindungi masyarakat dari praktik-praktik pendidikan yang tidak professional, dan (c)meningkatkan kesejahteraan kekonseloran.

Sekedar perbandingan di AS th 1977 telah disertifikasi oleh dua badan, (NBCC dan NCE) untuk menjadi profesional. Menurut Willys bahwa pada akhir th 1987 hampir 17.500 konselor telah disertifikasi, rata-rata NBCC mengeluarkan 1000 sertifikat tiap tahun, sehingga saat ini (2003) sudah 40.000 konselor telah disertifikasi.

Hasil wawancara 12 September 2012 dua kepala sekolah di Makassar, yaitu SMAN 3 dan 8. Kepala SMAN 3 menyatakan bahwa kinerja konselor belum bisa dibedakan dengan dua bentuk sertifikasi (portopolio dan pelatihan). Demikian juga kepala SMAN 8 ragu menyatakan penilaian kinerja sebelum dan sesudah konselor mendapatkan sertifikasi tidak bisa dinilai. Lebih lanjut dipertanyakan bahwa sertifikasi dan kinerja bahkan motivasi dan kepuasan kerja berpengaruh atau tidak. Pertanyaannya adalah: (1) Bagaimana potret sudah sertifikasi dan belum sertifikasi, baik dengan sertifikasi portofolio maupun pelatihan terhadap kinerja guru BK di sekolah? , (2) Apakah ada pengaruh sertifikasi terhadap motivasi kerja dan kepuasan kerja?, (3) Apakah ada pengaruh motivasi kerja dan kepuasan kerja terhadap kinerja konselor?, (4) Apakah ada 
pengaruh kepuasan kerja konselor terhadap motivasi kerja konselor?

Kartadinata, S. dkk, (2005:136) mengemukakan tujuan bimbingan dan konseling adalah agar konseli dapat : (1) merencanakan kegiatan studi, perkembangan karier, serta kehidupan di masa yang akan datang, (2) mengembangkan potensi dan kekuatan yang dimiliki, (3) menyesuaikan diri dengan lingkungan masyarakat serta lingkungan kerjanya, dan (4) mengatasi hambatan dan kesulitan yang dihadapi. Menurut Sikun (Oemar. 2008:4) mengemukakan definisi bahwa profesi itu pada hakekatnya adalah suatu pernyataan atau suatu janji terbuka, bahwa seseorang akan mengabdikan dirinya kepada suatu jabatan atau pekerjaan. Hal ini mengandung aspek bahwa (1) hakekat profesi adalah suatu pernyataan atau suatu janji yang terbuka, (2) profesi mengandung unsur pengabdian, dan (3) profesi adalah jabatan atau pekerjaan.

Teori tentang Kinerja Konselor menurut Mc.Clelland (Sholeh, 2008:1145) bahwa ada hubungan yang positif antara motivasi kerja dan kinerja seseorang. Artinya setiap pekerja yang memiliki motivasi kerja tinggi akan menghasilkan prestasi kerja yang tinggi pula. Unjuk kerja guru bimbingan dan konseling dalam melaksanakan tugas dan tanggung jawab, wewenang, dan haknya secara penuh dalam pelaksanaan bimbingan dan konseling terhadap sejumlah siswa. Sajidan (2011:3) bahwa peningkatan mutu guru bimbingan dan konseling harus memiliki karakter yang kuat dan cerdas untuk mampu mengembangkan kualitas konseling yang bermutu dimana pada akhirnya berdampak pada peningkatan kualitas kinerja.

Penilaian kinerja konselor oleh Hartono (2011:3) bahwa peran konselor sebagai pengampu ahli pelayanan BK yang memandirikan peserta didik sebagai konseli. Lebih lanjut beliau kemukakan bahwa ada empat jenis komponen pelayanan dan empat jenis kinerja guru BK ahli, (1) komponen pelayanan dasar (tugas-tugas perkembangan), (2)komponen pelayanan responsif (pribadi dan emosi), (3) komponen pelayanan individu (masa depan), dan (4) komponen pelayanan dukungan sistem (kinerja). Selanjutnya, fungsi manajemen pelayanan bimbingan dan konseling menurut Kartadinata,S dkk, (2008:200-202) adalah perencanaan, pelaksanaan, evaluasi, analisis penilaian dan tindak lanjut. Uraian singkat berikut bahwa kegiatan awal bimbingan dan konseling dalam penyusunan program adalah asesmen. Asesmen dalam mengidentifikasi aspek-aspek yang menjadi bahan masukan penyusunan program. Pelaksanaan program pada setiap pelayanan, yaitu pelayanan dasar, pelayanan responsif, perencanaan individual dan dukungan sistem. Penilaian bertujuan untuk tindakan atau proses menentukan derajat kualitas kemajuan kegiatan pelaksanaan aspek tertentu sesuai dengan program. Dan tindak lanjut merupakan tindakan penilaian lebih lanjut adanya keberhasilan tindakan.

Pengertian Motivasi Kerja menurut Sardiman AM (2009: 89) bahwa motif adalah daya penggerak dari dalam subjek untuk melakukan kegiatan tertentu demi mencapai suatu tujuan. Motivasi adalah sebagai daya penggerak yang telah menjadi aktif pada saatsaat tertentu, terutama jika kebutuhan untuk mencapai tujuan sangat dirasakan/mendesak Selanjutnya, dikemukakan oleh Mitchell (Winardi, J.2002:1) bahwa “... motivasi mewakili proses-proses psikologikal yang menyebabkan timbulnya, diarahkannya, dan terjadinya persistensi kegiatan-kegiatan sukarela yang diarahkan ke tujuan tertentu ". Jadi motivasi adalah penggerak dari dalam diri seseorang untuk melakukan suatu perbuatan atau bertingkah laku dalam mencapai suatu tujuan.

Jenis-jenis motivasi kerja menurut Dimyati dan Mudjiono ada dua jenis motivasi, yaitu primer dan sekunder. Motivasi primer adalah motivasi yang didasarkan pada motifmotif dasar, terutama berasal dari aspek fisik manusia. Jenis sekunder yaitu motivasi yang dapat dipelajari, karena itu bekerja dengan baik harus dipelajari. Kedua jenis motivasi ini berguna bagi seseorang untuk mencapai sesuatu tujuan yang ingin dicapai.

Teori-teori motivasi kerja menurut Mc.Clelland (dalam Siagian P.S, 1989: 167-171) merumuskan tentang teori motivasi ada empat jenis kebutuhan, (1) Need for Achievement ( $n$ Ach), (2) Need for Power ( $n$ Po), (3) Need for Affiliation ( $n$ Aff) dan (4) Need for Autonomy ( $n$ Aut). Need for Achievement ( $\mathrm{Ach}$ ), kebutuhan untuk berprestasi tercermin pada dorongan untuk meraih kemajuan dan mencapai prestasi sesuai dengan standar yang telah ditetapkan. Need for Power ( $\mathrm{P} \mathrm{Po}$ ) adalah kebutuhan untuk berkuasa 
yang tampak pada keinginan mempengaruhi orang lain yang berinteraksi dengan dirinya. Need for Affiliation adalah kebutuhan berafiliasi dengan membangun persahabatan serta berhubungan hangat dengan orang lain. Need for Autonomy (n Aut) adalah kebutuhan tidak menggantungkan diri pada orang lain .

Pengertian kepuasan kerja menurut Wexley dan Yukl (1977:67) menyatakan bahwa sebagai perasaan seseorang terhadap pekerjaan. Tiffin (As'ad, 1987:105) mengemukakan kepuasan kerja berhubungan erat dengan sikap terhadap pekerjaan itu sendiri, situasi kerja dan kerja sama antara pimpinan dengan sesama pekerja. Luthans (2006:243) kepuasan kerja adalah hasil dari persepsi karyawan mengenai seberapa baik pekerjaan mereka memberikan hal yang dinilai penting. Dapat disimpulkan bahwa konsep kepuasan kerja bersifat individual hasil interaksi seseorang dengan lingkungan kerjanya.

Teori kepuasan kerja menurut Luthans (2006:245) ada 4, yaitu (1) discrepancy theory, (2) equity theory, (3) two factor theory, dan (4) control theory. Diskrepansi kepuasan kerja tergantung pada antara should be (expectation needs atau values) dengan apa yang menurut perasaannya telah diperoleh hasil pekerjaan.Teori equity bahwa orang akan merasa puas atau tidak, tergantung pada apakah ia merasakan keadilan atau tidak. Teori dua faktor bahwa kepuasan kerja tidak merupakan variabel yang kontinum. Sikap seseorang terhadap pekerjaan ada dua yaitu satisfiers (motivator) merupakan sumber kepuasan kerja, dissatisfiers (hygiene factor) ialah faktor yang terbukti menjadi sumber ketidakpuasan. Teori kontrol merupakan fenomena kognitif yang berhubungan dengan individu merasa mengontrol tingkat kehidupan mereka sendiri atau pekerjaan mereka.

Dasar Hukum Sertifikasi UU RI No. 20 Tahun 2003 tentang SPN, UU RI No. 14 Tahun 2005 tentang Guru dan Dosen, dan PP RI No. 19 Tahun 2005 tentang SNP. Di mana menyatakan bahwa guru BK adalah pendidik profesional. Karena itu, dipersyaratkan untuk memiliki kualifikasi akademik minimal Sarjana atau Diploma IV yang relevan dan menguasai kompetensi sebagai agen pembelajaran. Permendiknas No. 18 tahun 2007 mengemukakan bahwa sertifikasi guru BK dalam jabatan dilaksanakan melalui uji kompetensi.
Kompetensi pada Kepmendiknas No. 045/U/2005 diartikan sebagai seperangkat tindakan cerdas dan penuh tanggung jawab yang dimiliki seseorang .

Pengertian sertifikasi menurut Samani, M. dkk (2010:3) adalah penguasaan pengajaran dan pendidikan beserta perangkat-perangkat pembelajaran dilakukan secara sistematis, baik portofolio maupun pelatihan atau PLPG. Tujuan sertifikasi (1) tentukan kelayakan guru BK dalam melaksanakan tugas, (2) proses dan hasil pembelajaran, (3)guru sejahtera dan (4) tingkatkan martabat. Kompetensi profesional dinilai bukti fisik kualifikasi akademik, pendidikan dan pelatihan, pengalaman mengajar, perencanaan dan pelaksanaan pembelajaran, prestasi akademik, dan karya pengemban profesi. Pola sertifikasi guru BK dalam jabatan dilakukan dua cara, yaitu portofolio dan pelatihan.

Pola Sertifikasi guru BK dalam Jabatan Melalui Portofolio. Portofolio adalah (1)laporan lengkap tentang segala aktivitas seseorang, (2) kumpulan dari berbagai keterampilan, ide, minat, dan keberhasilan seseorang, (3) kumpulan laporan tugas dan penelitian yang memberikan gambaran perkembangan yang bersangkutan setiap saat, (4) upaya penilaian melalui pendekatan nyata, (5) penilaian dengan presentasi berbagai hal proses yang terjadi yang ditampilkan seseorang. Dikemukakan oleh Hartono (2011) bahwa motivasi guru dalam program sertifikasi dalam jabatan didorong oleh motivasi finansial, bukan motivasi pengembangan kompetensi. Hal yang sama dikemukakan Ditjen PMPTK bahwa motivasi terkait dengan finansial. Mc.Clelland (Sholeh. 2001:1144) menyatakan bahwa ada hubungan yang positif antara motivasi kerja dan kinerja seseorang. Artinya setiap pekerja memiliki motivasi kerja yang tinggi dapat mendukung kinerja yang tinggi pula atau hasil kerja yang memadai.

Luthans (2005:243) mengemukakan lima dimensi seorang menjadi puas atau tidak puas dari suatu pekerjaan, yaitu: (1) pekerjaan itu sendiri, (2) gaji, (3) kesempatan promosi, (4) pengawasan, dan (5) rekan kerja. Lebih lanjut dia kemukakan bahwa kinerja adalah sesuatu yang terkait dengan hasil prilaku. Wiener (Daft, 2000:106) menemukan bahwa ketika kesesuaian dimensi-dimensi ini terjadi pada suatu pekerjaan, para pekerja yang berkomitmen tinggi akan 
menciptakan sebuah organisasi yang berkinerja tinggi yang sulit dikalahkan.

Berdasarkan latar belakang dan kajian pustaka diatas maka tujuan penelitian ini adalah untuk mengetahui (i) potret atau gambaran deskripsi sertifikasi bentuk portofolio dan pelatihan terhadap motivasi kerja, kepuasan kerja dan kinerja guru bimbingan dan konseling, (ii) pengaruh sertifikasi terhadap motivasi kerja, kepuasan kerja dan kinerja konselor, (iii) pengaruh motivai kerja dan kepuasan kerja terhadap kinerja konselor dan (iv) pengaruh kepuaan kerja terhadap motivasi kerja konselor.

Hipotesis Penelitian : (1) Ada perbedaan kinerja, kepuasan kerja dan motivasi kerja guru bimbingan dan konseling menurut status sertifikasi (portofolio, pelatihan, dan belum tersertifikasi). (2) Status sertifikasi berpengaruh terhadap kinerja, motivasi kerja dan kepuasan kerja guru bimbingan dan konseling di sekolah. (3) Motivasi kerja dan kepuasan kerja berpengaruh terhadap kinerja guru bimbingan dan konseling yang sudah tersertifikasi portofolio di sekolah. (4) Motivasi kerja dan kepuasan kerja berpengaruh terhadap kinerja guru bimbingan dan konseling yang sudah tersertifikasi pelatihan di sekolah. (5) Motivasi kerja dan kepuasan kerja berpengaruh terhadap kinerja guru bimbingan dan konseling yang belum tersertifikasi di sekolah.

\section{METODE PENELITIAN}

Penelitian ini menggunakan pendekatan kuantitatif dengan bentuk survei dengan teknik stratified random sampling (area sampling). Penelitian ini menggunakan desain analisis Structural Equation Model (SEM) dan bentuk Analysis of Moment Structures (AMOS) Selain itu, analisis juga dilakukan dengan analisis Regresi dan Analisis Variansi (Tiro. 2010a dan 2010b). Sertifikasi konselor sebagai variabel independent atau eksogen (mempengaruhi), motivasi dan kepuasan kerja konselor sebagai variabel antara atau mediasi, variabel kinerja

Desain Penelitian dikemukakan sebagai berikut. konselor sebagai variabel dependent atau endogen (dipengaruhi).

Definisi operasional variabel : (1) Kinerja guru bimbingan dan konseling adalah skor total yang diperoleh dari skala penilaian kinerja guru bimbingan dan konseling yang menggambarkan intensif atau tidaknya guru bimbingan dan konseling melakukan tindakan perencanaan, pelaksanaan, penilaian, analisis penilaian dan tindak lanjut dalam pelayanan program bimbingan dan konseling di sekolah, khususnya SMA Negeri di Sulawesi Selatan. (2). Motivasi kerja adalah penjabaran dari komponenkomponen dorongan kerja yang mencakup kebutuhan berprestasi, kebutuhan berkuasa, kebutuhan berafiliasi dan kerbutuhan kemandirian. Kebutuhan berprestasi yang meliputi dorongan untuk menjadi unggul, tanggung jawab secara pribadi, menyenangi tantangan, menetapkan tujuan realistik, menginginkan umpan balik, memiliki semangat tinggi dan bekerja keras. Kebutuhan berkuasa yang meliputi mampu mempengaruhi orang lain, mengendalikan orang lain dan menyukai persaingan. Kebutuhan berafiliasi yang meliputi membangun persahabatan, ingin untuk disukai, menikmati kegiatan sosial dan keinginan rasa memiliki. Kebutuhan kemandirian yang meliputi tidak tergantung pada orang lain, mengendalikan tugas-tugasnya sendiri dan tidak ingin dirintangi oleh aturan atau prosedur berlebihan. (3). Kepuasan kerja adalah suasana dan kondisi dimana guru bimbingan dan konseling dalam keadaan menyenangkan pada pekerjaan itu sendiri, gaji yang memadai, promosi pekerjaan yang produktif, pengawasan yang kondusif dan kerja kelompok yang harmonis serta ada rasa bahagia pada waktu atau setelah menyelesaikan suatu pekerjaan bimbingan dan konseling sekolah dimana dia bekerja. (4) sertifikasi konselor adalah kegiatan/usaha meningkatkan keprofesionalan konselor melalui fortopolio dan pelatihan. 


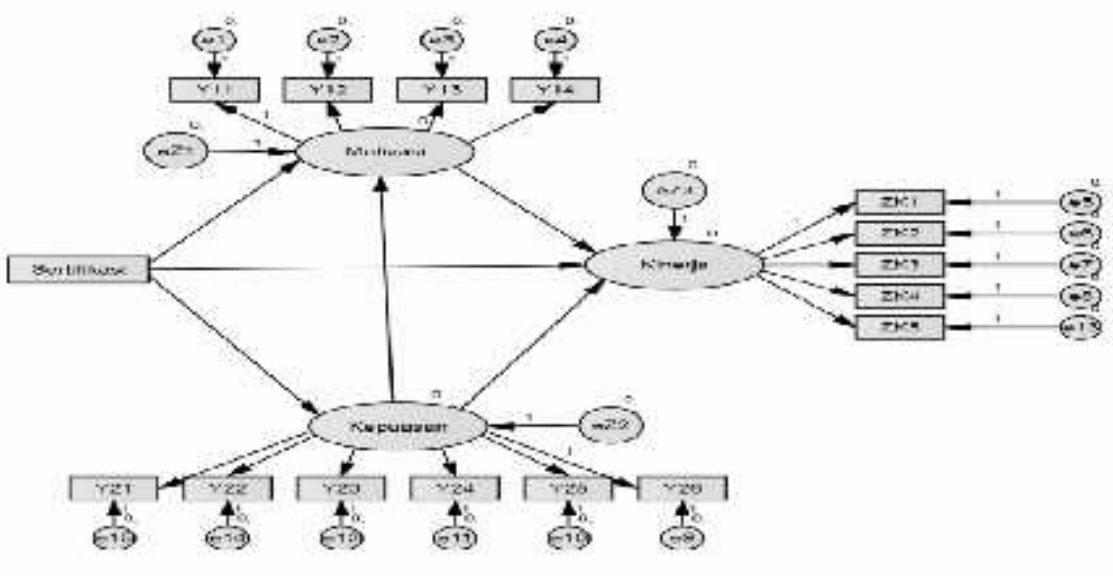

Gambar 3.1. Desain Penelitian

Populasi penelitian ini mencakup seluruh guru BK SMAN di Sul-Sel yang telah sertifikasi dan belum sertifikasi yang berijazah Sarjana Psikologi Pendidikan dan Bimbingan (Bimbingan dan Konseling) dengan jumlah sebanyak 373 orang, rincian 319 orang lulus portofolio/pelatihan dan belum sertifikasi 54 orang. Menarik sampel secara acak dengan teknik stratified random sampling (area sampling) pada daerah Timur, Selatan, Tengah dan Utara. Jumlah sampel seluruhnya sebanyak 163 orang. Teknik pengumpulan data yang digunakan adalah skala penilaian (quesioner) dan dokumentasi . Skala penilaian ini disusun dalam bentuk pernyataan tertutup, dengan menggunakan skala Likert pada rentang nilai 0 4. Kategori pernyataan ada positif dan negatif, analisis uji kekonsistenan internal dengan koefisien korelasi, uji kesahihan konstruk dengan analisis faktor konfirmatori dan menghitung koefisien keandalan dengan koefisien alpha Crombach. Selain itu dokumentasi juga digunakan sebagai pengumpulan data dengan mencatat program kerja, satuan layanan (RPBK), catatan kasus, konferensi kasus, konsultasi orangtua, konseling siswa, dan sebagainya.

\section{HASIL DAN PEMBAHASAN}

\section{Hasil}

Analisis deskriptif variabel kinerja, motivasi dan kepuaan kerja guru BK..

Tabel 4.1 Analisis Mean, Median, Standard Deviasi, Kurtosis dan Skewness

\begin{tabular}{l|c|c|c|c}
\hline \multicolumn{1}{c|}{ Deskripsi } & $\begin{array}{c}\text { Kiner. } \\
\text { Konselor }\end{array}$ & Motivasi & Kepuasan & $\begin{array}{c}\text { Kiner. } \\
\text { Pimpin }\end{array}$ \\
\hline Mean & 124.0798 & 106.7669 & 113.6135 & 119.3558 \\
\hline Std. Error of Mean & .75374 & .78695 & .95281 & .91627 \\
\hline Median & 123.0000 & 106.0000 & 114.0000 & 121.0000 \\
\hline Mode & 121.00 & 102.00 & $112.00^{\mathrm{a}}$ & 130.00 \\
\hline Std. Deviation & 9.62313 & 10.04715 & 12.16468 & 11.69820 \\
\hline Variance & 92.605 & 100.945 & 147.979 & 136.848 \\
\hline Kurtosis & .092 & 1.657 & .686 & .521 \\
\hline Skewness & .228 & -.529 & -.388 & -.526 \\
\hline & & & & \\
\hline
\end{tabular}


mean atau rata-rata, median dan standard deviation dapat diliat pada Tabel 4.1. dari table itu dapat dilihat bahwa kinerja, motivasi dan kepuasan kerja guru bimbingan dan konseling cenderung bervariasi, tetapi tidak memiliki perbedaan yang signifikan. Selanjutnya, kurtosis dan skewness menunjukkan nilai masing-masing kinerja . menunjukkan garis normalitas, tidak mengarah ke kiri atau mengarah ke kanan secara ekstrim.

\section{Hasil Analisis Statistik Inferensial dengan} Analisis Jalur dapat dilihat pada tabel 4.2 dalam tabel itu terlihat pengaruh sertifikasi guru BK terhadap variabel lain.

Tabel 4.2 Koefisien Jalur Variabel Sertifikasi Dengan Variabel Lain

\begin{tabular}{l|c|l|c|l|l|l|l}
\hline & & & Estimate & S.E. & C.R. & P & Label \\
\hline Kepuasan & $\leftarrow-$ & Sertifikasi & .484 & .040 & 12.212 & 0.001 & \\
\hline Motivasi & $\leftarrow-$ & Sertifikasi & -.819 & .088 & -9.315 & 0.001 & \\
\hline Motivasi & $\leftarrow-$ & Kepuasan & 1.351 & .176 & 7.654 & 0.001 & \\
\hline Kinerja & $\leftarrow-$ & Sertifikasi & .081 & .041 & 2.003 & .045 & \\
\hline Kinerja & $\leftarrow-$ & Kepuasan & .102 & .070 & 1.463 & .144 & \\
\hline Kinerja & $\leftarrow-$ & Motivasi & .138 & .040 & 3.470 & 0.001 & \\
\hline
\end{tabular}

Dengan demikian disimpulkan bahwa sertifikasi guru BK berpengaruh terhadap kepuasan kerja, motivasi kerja, kinerja konselor dan kepuasan kerja berpengaruh terhadap motivasi kerja dan motivasi kerja berpengaruh terhadap kinerja konselor.

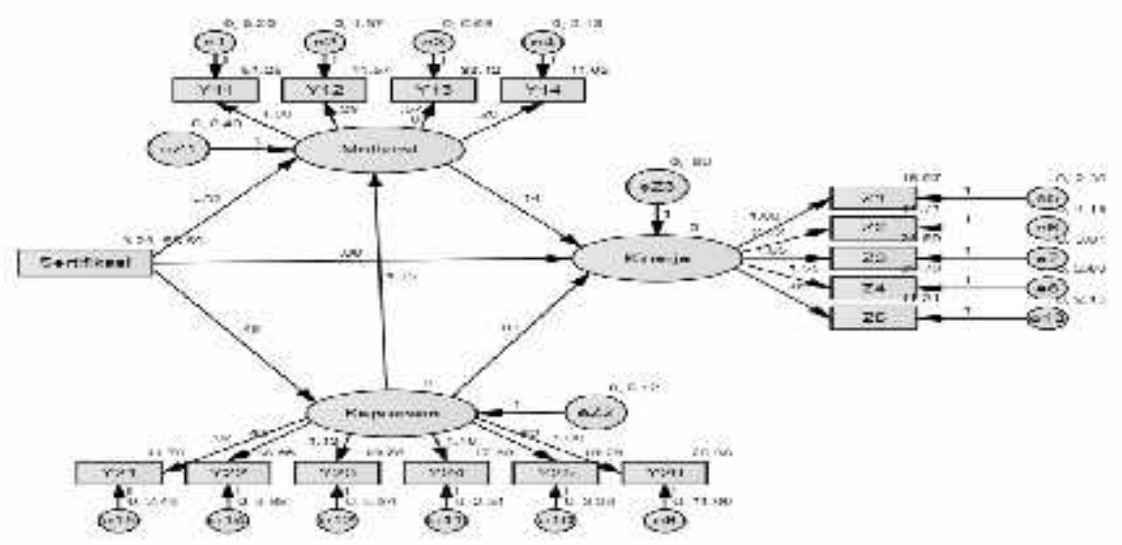

Gambar 3.2 Kinerja Konselor oleh Penilaian Diri Sendiri

Analisis sertifikasi portofolio terhadap kinerja guru BK disajikan dalam tabel 4.3 tabel ini dapat dilihat bahwa sertifikasi guru BK dalam bentuk portofolio berpengaruh terhadap variabel linnya.

Tabel 4.3 Koefisien Jalur Sertifikasi Portofolio terhadap Motivasi, Kepuasan Kerja dan Kinerja Guru BK

\begin{tabular}{ll|llll}
\hline & Estimate & S.E. & C.R. & P \\
\hline Motivasi $\leftarrow-$ & Kepuasan & .475 & .198 & 2.404 & 0.05
\end{tabular}




\begin{tabular}{lll|lrrr}
\hline & & & Estimate & S.E. & C.R. & P \\
\hline Kinerja & $\leftarrow-$ & Kepuasan & -.037 & .137 & -.274 & .784 \\
Kinerja & $\leftarrow-$ & Motivasi & .767 & .313 & 2.453 & 0.05 \\
\hline
\end{tabular}

Dengan demikian disimpulkan bahwa sertifikasi guru BK dalam bentuk portofolio berpengaruh secara signifikan motivasi kerja terhadap kinerja

konselor dan kepuasan kerja terhadap motivasi kerja beserta semua indikator-indikatornya.

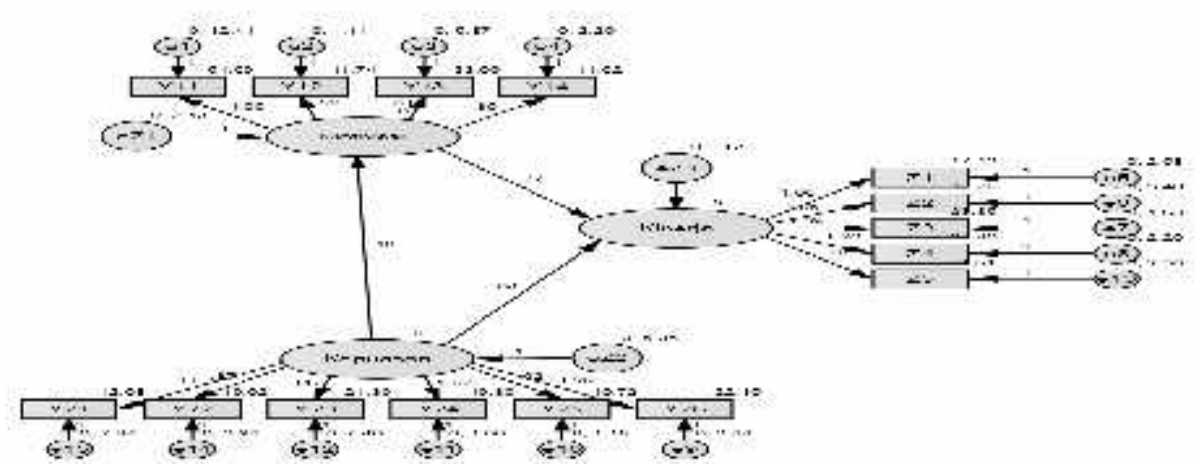

Gambar 3.4 Data Sertifikasi Portofolio terhadap Motivasi, Kepuasan dan Kinerja

Analisis Kinerja Konselor dengan Sertifikasi Pelatihan. Disajikan dalam tabel 4.4, dalam tabel ini dapat dilihat pengaruh sertifikasi melalui pelatihan terhadap varabel lainnya

Tabel 4.4 Koefisien Jalur Pelatihan terhadap Motivasi, Kepuasan dan Kinerja

\begin{tabular}{l|l|l|l|l|l|l|l}
\hline & & & Estimat & S.E. & C.R. & P & Label \\
\hline Motivasi & $\leftarrow-$ & Kepuasan & 1.986 & .494 & 4.018 & .001 & \\
\hline Kinerja & $\leftarrow-$ & Kepuasan & .115 & .103 & 1.116 & .264 & \\
\hline Kinerja & $\leftarrow-$ & Motivasi & .076 & .038 & 2.018 & .044 & \\
\hline
\end{tabular}

Dapat disimpulkan sertifikasi bentuk pelatihan berpengaruh secara signifikan kepuasan kerja terhadap motivasi dan kinerja guru BK. 


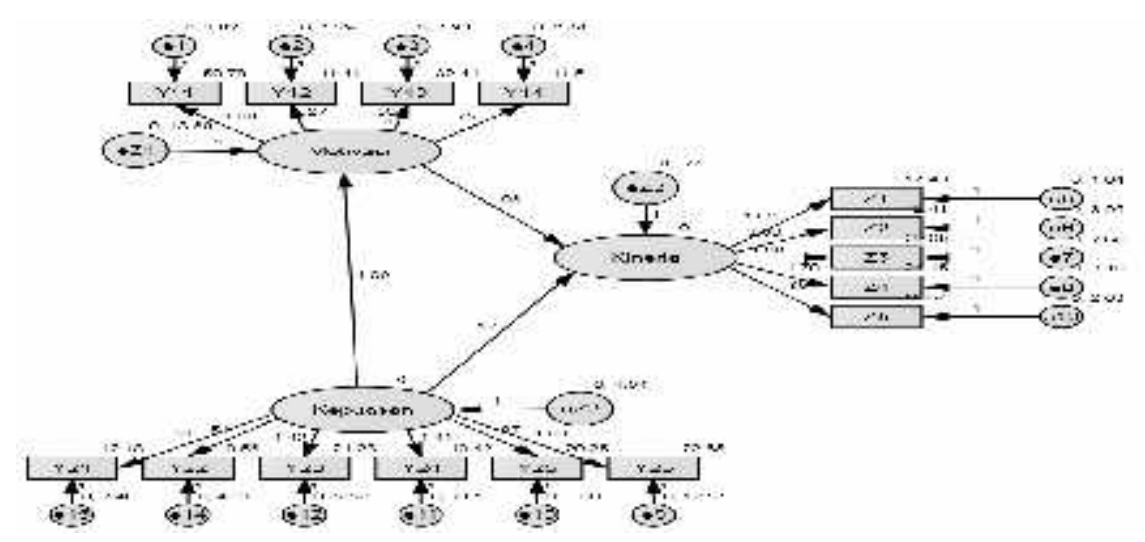

Gambar 3.5 Sertifikasi Pelatihan terhadap Motivasi, Kepuasan dan Kinerja

Hasil Analisis Kinerja Konselor yang dan kinerja guru BK dapat dilihat pada tabel 4.5 Belum tersertifikasi terhadap motivasi, kepuasan

Tabel 4.5 Koefisien Jalur Belum Sertifikasi terhadap Motivasi, Kepuasan Kerja dan Kinerja Guru BK

\begin{tabular}{l|l|l|c|c|c|c|l}
\hline & & & Estimate & S.E. & C.R. & P & Label \\
\hline Motivasi & $\leftarrow-$ & Kepuasan & 1.131 & .451 & 2.507 & .012 & \\
\hline Kinerja & $\leftarrow-$ & Kepuasan & .185 & .278 & .664 & .507 & \\
\hline Kinerja & $\leftarrow-$ & Motivasi & .077 & .217 & .357 & .721 & \\
\hline \hline
\end{tabular}

Motivasi kerja dan kepuasan kerja terhadap kinerja konselor menunjukkan nilai $\mathrm{p}>$ 0,05. Demikian juga indikator-indikator dari kepuasan kerja terhadap kinerja, yaitu rekan kerja dan pekerjaan itu sendiri. Hal ini menunjukkan bahwa konselor yang belum sertifikasi tidak berpengaruh kepuasan kerja dan motivasi kerja terhadap kinerja konselor.

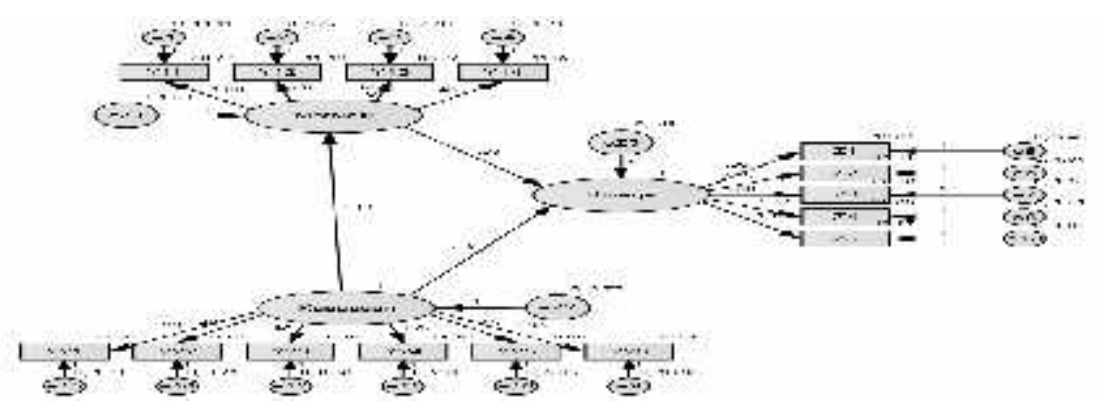

Gambar 3.6 Data Sebelum Sertifikasi terhadap Motivasi, Kepuasan Kerja, dan Kinerja 
Tabel 4.6 Analisis Kinerja, Bentuk Sertifikasi dan Interpretasi

\begin{tabular}{l|c|l}
\hline Kinerja/ Sertifikasi & Nilai $\mathrm{p}$ & \multicolumn{1}{c}{ Interpretasi } \\
\hline Kinerja guru BK & 0,05 & $\begin{array}{l}\text { Sertifikasi berpengaruh terhadap kepuasan, motivasi dan } \\
\text { kinerja, sedangkan Kepuasan tidak berpengaruh terhadap } \\
\text { kinerja. }\end{array}$ \\
\hline Sertifikasi portofolio & 0,05 & $\begin{array}{l}\text { Motivasi berpengaruh terhadap kinerja, sedangkan } \\
\text { kepuasan tidak berpengaruh terhadap kinerja, }\end{array}$ \\
\hline Sertifikasi Pelatihan & 0,05 & $\begin{array}{l}\text { Motivasi berpengaruh terhadap kinerja, sedangkan } \\
\text { kepuasan tidak berpengaruh terhadap kinerja. }\end{array}$ \\
\hline Belum Sertifikasi & 0,05 & $\begin{array}{l}\text { Kepuasan berpengaruh terhadap motivasi, tetapi motivasi } \\
\text { \& kepuasan tidak berpengaruh terhadap kinerja. }\end{array}$ \\
\hline
\end{tabular}

Demikian interpretasi secara umum dapat ditarik terhadap kepuasan kerja guru BK., berikut. kesimpulan, bahwa kinerja tidak berpengaruh

Tabel 4.7 Tabel Anava dari variabel Motivasi, Kepuasan dan Kinerja

\begin{tabular}{l|l|c|c|c}
\hline Variabel & Kelompok & Sum of Squares & Mean Square & $\mathrm{p}$ \\
\hline Motivasi & Antar Kel & 65.573 & 32.786 & .725 \\
\hline & Dlm Kel & 16287.568 & 101.797 & \\
\hline & Total Nilai & 16353.141 & & \\
\hline Kepuasan & Antar Kel & 756.081 & 378.040 & .077 \\
\hline & Dlm Kel & 23216.470 & 145.104 & \\
\hline & Total Nilai & 23972.650 & & \\
\hline Kin. kons & Antar Kel & 88.980 & 44.490 & .621 \\
\hline & Dlm Kel & 14912.983 & 93.206 & \\
\hline & Total Nilai & 15001.963 & & \\
\hline
\end{tabular}

Tabel 4.7 menunjukkan bahwa motivasi kerja, kepuasan kerja dan kinerja guru bimbingan dan konseling memiliki nilai $\mathrm{p}>0,05$, yang berarti bahwa tidak ada perbedaan motivasi kerja, kepuasan kerja dan kinerja guru bimbingan dan konseling.

(2). Anava khusus untuk penilaian kinerja Guru BK, berikut.

Tabel 4.8 Analisis Variansi Kinerja Guru BK

\begin{tabular}{l|c|c|c}
\hline Kelompok & Sum of squares & Mean squares & $\mathrm{p}$ \\
\hline Antar kelompok & 225.441 & 112.720 & .392 \\
\hline Dalam kelompok & 38764.596 & 120.014 & \\
\hline Total & 38990.037 & & \\
\hline
\end{tabular}

Tabel 4.8 dijelaskan bahwa taraf signifikansi pada variabel motivasi semua bentuk sertifikasi dari tiga taraf, yaitu aspek pasangan pelatihan dan portofolio serta belum sertifikasi, nilai $\mathrm{p}>$
0,05. Hal ini dapat disimpulkan bahwa, pada variabel motivasi tidak ada perbedaan bentuk sertifikai pelatihan, portofolio dan belum sertifikasi. 
Tabel 4.9 Perbandingan Ganda Sertifikasi dan Motivasi

\begin{tabular}{l|c|c|c}
\hline & Perbedaan Rerata & Standar kesalahan & $\mathrm{p}$ \\
\hline Belum-Portofolio & -0.52 & 2.28 & 0.82 \\
\hline Belum-Pelatihan & 0.89 & 2.14 & 0.68 \\
\hline Portofolio-Pelatih & 1.41 & 1.79 & 0.43 \\
\hline
\end{tabular}

Hal ini dapat disimpulkan bahwa, pada variabel motivasi tidak ada perbedaan bentuk sertifikai pelatihan, portofolio dan belum sertifikasi.

Tabel 4.10 Perbandingan Ganda Sertifikasi dan Kepuasan Kerja Konselor

\begin{tabular}{l|c|c|c}
\hline Aspek Sertifikasi & Beda Rerata & Stand. Kesalahan & $\mathrm{p}$ \\
\hline Belum-Portofolio & $-4,11$ & 2,72 & 0,13 \\
\hline Belum-Pelatihan & $-5,83$ & 2,55 & 0,02 \\
\hline Portofolio-Pelatih & $-1,71$ & 2,14 & 0,43 \\
\hline
\end{tabular}

Demikian dapat disimpulkan bahwa tidak ada perbedaan kepuasan kerja konselor dengan bentuk sertifikasi guru BK, baik bentuk portofolio-pelatihan maupun belum sertifikasiportofolio, kecuali belum sertifikasi-sertifikasi pelatihan.

Tabel 4.11 Perbandingan Ganda Sertifikasi dan Kinerja Guru BK

\begin{tabular}{l|c|c|c}
\hline Aspek Sertifikasi & Beda Rerata & Stand Kesalahan & $\mathrm{p}$ \\
\hline Belum-Portofolio & $-1,53804$ & 2,18295 & 0,482 \\
\hline Belum-Pelatihan & $-1,99469$ & 2,04609 & 0,331 \\
\hline Portofolio-Pelatihan & $-0,45665$ & 1,71419 & 0,790 \\
\hline
\end{tabular}

Demikian dapat disimpulkan bahwa perbandingan belum sertifikasi dan sudah sertifikasi (portofolio dan pelatihan) menunjukkan tidak ada perbedaan.

\section{Pembahasan}

Hasil pengujian hipotesis pertama dengan analisis deskripsi dan Anava pada penilaian kinerja guru BK menunjukkan bahwa, potret kinerja konselor di sekolah berpengaruh terhadap guru BK yang sudah sertifikasi (portofolio dan pelatihan) maupun konselor yang belum sertifikasi pada semua variabel. Demikian juga analisis varians menunjukkan tidak ada perbedaan kinerja guru BK terhadap bentuk sertifikasi portofolio dan pelatihan. Temuan ini mendukung ide dan tujuan pelaksanaan sertifikasi, baik portofolio maupun pelatihan atau PLPG. Lebih lanjut tentang kinerja ditemukan bahwa kepuasan kerja dan motivasi kerja tidak berpengaruh terhadap kinerja konselor. Dengan demikian dapat disimpulkan bahwa tidak ada pengaruh motivasi dan kepuasan kerja terhadap kinerja konselor.

Hasil pengujian hipotesisi kedua bahwa ada pengaruh sertifikasi terhadap motivasi kerja, kepuasan kerja dan kinerja konselor di sekolah. Sertifikasi konselor erat kaitannya dengan konsep motivasi dan kepuasan kerja konselor yang dibahas pada uaraian berikut ini. Menurut uraian Sardiman tentang salah satu jenis motivasi konselor yang memiliki motivasi, kerja intrinsik akan memiliki tujuan menjadi orang terdidik, berpengetahuan, dan menjadi ahli dalam bidangnya. Motivasi kerja intrinsik juga memiliki tujuan menjadi orang terdidik, terpelajar, santun dalam berkomunikasi kepada semua orang. Demikian pula halnya motivasi intrinsik yang memiliki tujuan menjadi orang yang berpengetahuan, tidak terbatas pada pengetahuan spesifik (khusus), tapi juga pengetahuan umum yang mendalam dan luas. 
Hasil pengujian hipotesis ketiga, yaitu ada pengaruh motivasi kerja terhadap kinerja konselor menurut penilaian kinerja diri sendiri, sebaliknya dengan penilaian pimpinan bahwa tidak ada pengaruh motivasi kerja terhadap kinerja konselor. Kepuasan kerja tidak berpengaruh terhadap kinerja konselor menurut penilaian pimpinan dan penilaian diri sendiri $\mathrm{Hal}$ ini juga ditunjukkan dalam dua analisis penilaian kinerja, penilaian kinerja atas diri sendiri (konselor) dan penilaian kinerja oleh pimpinan. Kepuasan kerja dan kinerja konselor berpengaruh terhadap sertifikasi konselor di sekolah, baik sertifiksi bentuk portofolio maupun sertifikasi bentuk pelatihan.

Hasil pengujian hipotesis keempat, yaitu ada pengaruh kepuasan kerja konselor terhadap motivasi kerja konselor di sekolah. Selanjutnya, sertifikasi berpengaruh terhadap motivasi kerja, kepuasan kerja dan kinerja konselor di SMA Negeri di Sulawesi Selatan. Sertifikasi menjadi pendorong utama, baik motivasi kerja maupun kepuasan kerja dan kinerja konselor. Demikian pula bahwa kepuasan kerja konselor berpengaruh terhadap motivasi kerja. Dengan demikian kepuasan kerja yang optimal dirasakan seseorang dari hasil pekerjaan yang diselesaikan secara memadai akan menjadi penyebab tinggi pula motivasi kerja seseorang pada pekerjaan itu.

\section{SIMPULAN DAN SARAN}

Untuk kesimpulan nomor satu di bawah ini adalah tentang potret sertifikasi guru bimbingan dan konseling, sedangkan nomor dua dan seterusnya adalah analisis koefisien jalur pengaruh berbagai bentuk sertifikasi terhadap motivasi kerja, kepuasan kerja dan kinerja guru bimbingan dan konseling.

1. Potret sertifikasi (portofolio dan pelatihan) tidak menunjukkan perbedaan kinerja yang signifikan. Distribusi motivasi, kepuasan kerja dan kinerja guru BK cenderung mengikuti distribusi normal.

2. Sertifikasi pelatihan menunjukkan bahwa kepuasan kerja berpengaruh positif terhadap motivasi kerja dan motivasi kerja berpengaruh positif terhadap kinerja guru BK, sehingga kepuasan kerja berpengaruh tidak langsung terhadap kinerja, tetapi melalui motivasi kerja.
3. Sertifikasi portofolio hasilnya sama dengan sertifikasi pelatihan, di mana dapat meningkatkan kepuasan kerja terhadap motivasi kerja dan motivasi kerja terhadap kinerja guru BK.

4. Belum sertifikasi menunjukkan bahwa kepuasan kerja berpengaruh positif terhadap motivasi kerja, tetapi kepuasan kerja dan motivasi kerja tidak berpengaruh signifikan terhadap kinerja guru BK.

Saran penelitian ini adalah:

1. Pemerintah hendaknya memberikan kesempatan yang seluas-luasnya kepada semua guru BK yang berijazah bimbingan dan konseling untuk mendapatkan kesempatan menempuh sertifikasi, baik bentuk portofolio yang berprestasi kerja tinggi maupun bentuk pelatihan (PLPG), karena pengaruhnya terhadap kepuasan kerja untuk meningkatkan kinerja secara profesional.

2. Penyelenggara sertifikasi hendaknya secara disiplin dan kritis, baik sertifikasi bentuk portofolio maupun sertifikasi bentuk pelatihan (PLPG), karena ada pengaruhnya terhadap motivasi kerja, kepuasan kerja dan kinerja guru BK.

3. Demi efektivitas biaya dan anggaran pendapatan dan belanja Negara dan Daerah, penyelenggara sertifikasi di daerah atau rayon setempat hendaknya memotivasi guru BK, agar dapat bertanggung jawab dan belajar secara benar dan bersungguh-sungguh yang dapat meningkatkan kinerja secara memadai.

4. Kepada guru BK pada umumnya sebaiknya menata diri dan meningkatkan kinerja dalam memotivasi diri dan pada akhirnya bekerja dengan penuh kepuasan untuk peningkatan mutu guru BK, agar bekerja secara profesional.

5. Para guru BK SMAN pada khususnya, hendaknya menggunakan kesempatan dengan bersungguh-sungguh belajar untuk menjadi guru BK yang benar-benar profesional dalam bidang Bimbingan dan Konseling.

6. Para peneliti disarankan untuk mengkaji lebih lanjut faktor-faktor yang menyebabkan perbedaan kinerja, motivasi kerja dan kepuasan kerja guru BK, khususnya mengenai pendidikan profesi guru BK dalam jabatan pada masa-masa selanjutnya. 


\section{DAFTAR RUJUKAN}

As'ad. 1987. Psikologi Industri. Yogyakarta: Liberty.

Kartadinata, S. 2005. Standar Kompetensi Guru bimbingan dan konseling Indonesia, Pengurus Besar Asosiasi Bimbingan dan Konse/wiki/guru bimbingan dan konseling.comling Indonesia. Bandung, diakses 23 September 2012.

Kartadinata, S. dkk. 2008. Penegasan Profesi Bimbingan dan Konseling, Alur Pikir Penataan Pendidikan Profesional Guru bimbingan dan konseling dan Layanan Bimbingan dan Konseling Dalam Jalur Pendidikan Formal. Bandung: Pengurus Pusat ABKIN.

Kementerian Pendidikan Nasional RI. 2010. Sertifikasi Guru Dalam Jabatan Buku 3 Pedoman Penyusunan Portofolio. Dikjen Dikti. Jakarta.

Luthans, Fred. 2006. Perilaku Organisasi (Terjemahan). Yogyakarta: Andi Yogyakarta.

Oemar Hamalik. 2008. Pendidikan Guru Berdasarkan Pendekatan Kompetensi. Jakarta: PT. Bumi Aksara.

Sajidan. 2011. Pengembangan Profesionalisme Guru dan Dosen. (Online situs tidak tercatat). February 25th, 2011/Category. Solo: FKIP UNS.

Samani, Muchlas dkk. 2009. Buku 2, 3, 4 \& 5. Petunjuk Teknis Pelaksanaan Sertifikasi. Jakarta: Direktorat Jenderal Pendidikan Tinggi Departemen Pendidikan Nasional.

2008. Buku 2, 3, 4 \& 5. Pedoman Sertifikasi Guru Dalam Jabatan Melalui Penilaian Portofolio. Jakarta: Direktorat Jenderal Pendidikan Tinggi Departemen Pendidikan Nasional.

2010. Buku 3. Pedoman Penyusunan Portofolio. Jakarta: Direktorat Jenderal Pendidikan Tinggi Kementerian Pendidikan Nasional.

Sardiman AM. 2009. Interaksi dan Motivasi Belajar Mengajar. Jakarta: Rajawali Pers.

Sholeh, Hidayat. 2008. Hubungan Minat Terhadap Profesi Guru dan Motivasi Berprestasi dengan Keterampilan
Mangajar. Jurnal Pendidikan dan Kebudayaan, No.075, Tahun Ke 14 Nopember 2008. email:sholhidayat@yahoo.com. Universitas Sultan Ageng Tirtayasa. 1140-1154.

Siagian, S.P. 1989. Teori Motivasi dan Aplikasinya. Jakarta: Bina Aksara.

2010. Metode Penelitian Pendidikan (Pendekatan Kuantitstif, Kualitatif, dan $R \& D)$. Bandung: Penerbit Alfabeta.

Tiro, M. A., Sukarna, Aswi. 2010a. Statistik Deskriptif Peubah Banyak. Makasar: Andira Pub.

Tiro, A.M. Sukarna dan Aswi. 2010b. Analisis Jalur. Makassar: Andira Publisher.s

Winardi, J. 2002. Motivasi \& Pemotivasian Manajemen. Jakarta: PT. RajaGrafindo Persada. 